Article

\title{
Hydrogen Generation from a Small-Scale Solar Photovoltaic Thermal (PV/T) Electrolyzer System: Numerical Model and Experimental Verification
}

\author{
Metin Gül ${ }^{1}$ and Ersin Akyüz ${ }^{2, *(D)}$ \\ 1 Engineering of Electrical and Electronics, Balıkesir University Institute of Science, 10154 Balıkesir, Turkey; \\ metin001674@gmail.com \\ 2 Electronics and Automation, Balıkesir University Vocational School, 10154 Balıkesir, Turkey \\ * Correspondence: akyuz11@gmail.com
}

Received: 27 April 2020; Accepted: 7 June 2020; Published: 10 June 2020

check for updates

\begin{abstract}
In this study, the electrical, electrochemical and thermodynamic performance of a PV/T electrolyzer system was investigated, and the experimental results were verified with a numerical model. The annual amounts of electrical and thermal energy from the PV/T electrolyzer system were calculated as $556.8 \mathrm{kWh}$ and $1912 \mathrm{kWh}$, respectively. In addition, the hydrogen production performance for the $\mathrm{PV} / \mathrm{T}$ electrolyzer was compared with that of a PV electrolyzer system. The amount of hydrogen was calculated as $3.96 \mathrm{~kg}$ annually for the PV system, while this value was calculated as $4.49 \mathrm{~kg}$ for the PV/T system. Furthermore, the amount of hydrogen production was calculated as $4.59 \mathrm{~kg}$ for a $65^{\circ} \mathrm{C}$ operation temperature. The electrical, thermal and total energy efficiencies of the PV/T system, which were obtained hourly on a daily basis, were calculated and varied between $12-13.8 \%, 36.1-45.2 \%$ and $49.1-58.4 \%$, respectively. The hourly exergy analyses were also carried out on a daily basis and the results showed that the exergy efficiencies changed between 13.8-14.32\%. The change in the electrolysis voltage was investigated by changing the current and temperature in the ranges of $200-1600 \mathrm{~mA} / \mathrm{cm}^{2} \mathrm{~A}$ and $30-65^{\circ} \mathrm{C}$, respectively. While the current and the water temperature varied in the ranges of $400-2350 \mathrm{~mA} / \mathrm{cm}^{2}$ and $28.1-45.8^{\circ} \mathrm{C}$ respectively, energy efficiency and exergy efficiency were in the ranges of $57.85-69.45 \%$ and $71.1-79.7 \%$, respectively.
\end{abstract}

Keywords: photovoltaic thermal system (PV/T); solar energy; exergy; PEM electrolyzer; hydrogen energy

\section{Introduction}

Nowadays, global warming and energy crises have become a serious problem threatening our future. The utilization of sustainable energy sources instead of fossil energy sources can deal with a wide range of factors associated with these problems [1]. Renewable energy sources such as solar, hydro, wind, and geothermal, which utilize natural elements and renew faster compared to consumption, have become the best alternatives for fossil sources [2].

With the advantage of high availability, solar energy is one of the most promising energy sources among those available for achieving a considerable amount of energy-saving and carbon emission reduction $[3,4]$. In this respect, photovoltaic (PV), solar thermal (STC), and hybrid photovoltaic/thermal (PV/T) systems are widely used today [5]. Regarding PV systems, a small amount of absorbed solar radiation is converted into electrical energy, and the remaining large amount of energy is converted into heat, which causes PV cell temperature to increase and electrical efficiency to reduce. This problem can be reduced by extracting the excessive amount of heat by a natural or induced fluid circulation system. The PV/T hybrid energy systems which contain integrated PV modules and heat extraction devices 
are efficient alternatives to PV systems by providing electricity and thermal energy concurrently [6]. Therefore, the design and optimization of PV/T hybrid energy systems have attracted attention from many researchers who carried out analyses both experimentally and theoretically [7-13].

According to these studies evaluating the performance of PV/T systems under different operating conditions and with different components, the total efficiency of PV/T varies between $47.4 \%$ and $80 \%[14,15]$. Additionally, there are also numerical and experimental researches on the performance analyses of PV/T systems in the literature. These studies mainly focus on building-integration [9], collectors with different coatings [16], improved laminated absorbers [17], low emissivity coatings [18], sheet and tubes [17,19], air PV/T [20,21] and commercial modules [22]. Some of the studies evaluating the efficiency of PV/T reported that the electrical efficiency of PV/T systems at appropriate fluid temperatures is higher than that of PV systems [23], and the total efficiency varies between $54.6 \%$ and $74.1 \%[23,24]$. In addition, performance analyses of PV/T systems with different PV technologies were completed to be utilized in PV/T exergy analyses $[25,26]$.

Guarracino et al. performed a techno-economic analysis of a PV/T system in two different climatic conditions, namely, Larnaca and London. The obtained electrical, thermal and total energy costs are 1.29 EUR/kWh, 0.34 EUR/kWh, 0.68 EUR/kWh, respectively, for Larnaca and $0.46 \mathrm{EUR} / \mathrm{kWh}$, $0.76 \mathrm{EUR} / \mathrm{kWh}, 0.50 \mathrm{EUR} / \mathrm{kWh}$, respectively, for London [27].

The storage of produced energy is important for both off-grid and on-grid systems due to the intermittent characteristic of renewable energy sources and the requirement of responding to an increase in instant energy [28]. Researchers have intensively studied the aforementioned systems concerning energy storage techniques such as batteries [29], storing heat with thermochemical heat storage materials [30] and phase-changing materials [31], capacitors [32], energy vectors and hydrogen [33]. By combining PV or PV/T systems with energy storage, such as hydrogen storage, it is possible to overcome these problems. It is a potential opportunity to produce hydrogen in an environmentally benign manner while producing electrical and thermal energy $[34,35]$. Despite existing as the most common element on Earth, hydrogen is found in compound forms, such as water, and can be produced from water with photo-catalysis, water electrolysis or thermo-chemical cycles [28,36,37].

Electrolysis, which uses electrical energy, was first discovered by W. Nicholson and Carlisle in 1800 , and the first large-scale electrolysis unit, with a hydrogen production capacity of $10000 \mathrm{Nm}^{3} / \mathrm{h}$, was produced in 1939. The first proton exchange membrane (PEM) electrolyzer was produced by General Electric in 1966 and it quickly gained interest from scientists due its compact system design and high voltage efficiency at current densities in comparison with traditional alkaline technology [38-45]. Apart from these features, a PEM electrolyzer can operate at up to 300 bar pressure and reach $95.1 \%$ efficiency at high temperatures [46].

Renewable energy sources have fluctuating and intermitting behavior, at this point PEM electrolyzers are more suitable options than alkaline electrolyzers due to their better dynamic behavior, since they have fast response time [1]. The utilization of solar radiation during the electrolysis process is a better alternative for storing energy, as it makes it cost-effective and environmentally friendly [47]. The feasibility and system performances of hybrid renewable energy systems for hydrogen production (mostly enhanced wind, solar, geothermal, and nuclear energy options) have been the focus of attention for many scientists [48].

PEM efficiency is affected by design and operating parameters. Parametric analyses were conducted to investigate the effect of such parameters on the efficiency of plant energy conversion. The results showed that energy efficiency of PEM electrolyzers increase with increasing temperature and decreases with current density. The impact of operating parameters of a PEM electrolyzer (such as current density and operating temperature) on energy efficiency was studied by Shekardasht et al. [28]. The operation temperature of the electrolyzer affects both the PEM energy and exergy efficiency. Several researchers have studied PV/T electrolyzer systems, supplying both low- and high-temperature hydrogen production. Corumlu et al. proposed a hybrid system, consisting of solar PV panels, solar heat pipe collectors, a heat exchanger, a separator and a PEM electrolyzer, and investigated 
the system thermodynamically. The research indicated that the solar collector, providing a higher PEM electrolyzer temperature with a higher supply of water, had a positive effect on the energy and exergy efficiency of the unit [49]. A similar system was studied by Aslan et al. using a compact $\mathrm{PV} / \mathrm{T}$ collector. The system performance was investigated under different climatic conditions with the numerical model, and the positive effect of a higher operation temperature on the PEM efficiency was highlighted [50].

Zafar and Dincer analyzed a combined PV/T and fuel-cell system for thermodynamic hydrogen production. In addition to the energy and exergy analyses, economic benefit analyses were also conducted. The results showed that the utilization of the extracted heat from the PV/T system increase the overall system energy efficiency from $15 \%$ to $50 \%$ [51].

Oruc et al. conducted finite-element analysis simulations for a PV/T E system in order to maximize overall energetic efficiency and hydrogen production, and consequently the change of energy efficiency of the system was calculated in the range of 56-59\% [52]. In addition, the performance of an integrated PV/T system for hydrogen production and cooling was analyzed by Ratlamwala et al. The impact of solar intensity, PV electrical output, electrolysis operating time, production of hydrogen and coefficient of performance (COP) were evaluated energetically and exergetically. The highest hydrogen production of the system was $9.7 \mathrm{~kg}$ and maximum energy and exergy efficiencies were $15.6 \%$ and $7.9 \%$, respectively [53].

A PV/T-driven hydrogen production system from the PEM electrolyzer was modeled thermodynamically. The energy and exergy analyses were conducted on a daily basis. The average energetic and exergetic efficiencies of the overall $\mathrm{PV} / \mathrm{T}$ were calculated as $29 \%$ and $14.11 \%$, respectively, and $0.018 \mathrm{~kg}$ hydrogen was produced by the PEM electrolyzer in a day [54].

Wang et al. proposed a system which utilizes solar heat and electricity energy for hydrogen production. A PV panel, a water preheater, and a PEM electrolyzer were used in the analyses of the numerical model for appraising and optimizing the thermodynamic performance of the hydrogen generation system. The change in electrical efficiency and surface temperatures of PV cells, energy-exergy efficiency, and solar to hydrogen efficiency of the system were analyzed in terms of different water flow rates, solar irradiations, PV emissivity and concentration ratios [1]. Furthermore, a solar-concentrated PV/T-driven hydrogen production method was developed. Organic Rankine cycle (ORC) was also coupled to the system to assist hydrogen production [55].

Based on the literature regarding PV/T electrolyzer systems, it is observed that there is a limited number of comprehensive numerical studies which include energy, exergy, and economic analysis together with experimental validation. A majority of the numeric or experimental studies in the literature have considered only one or two aspects, such as energy, exergy, or economic analysis. Furthermore, studies using the life-cycle methodology, on the comparison of hydrogen cost of photovoltaic-electrolyzer (PV-E) and photovoltaic/thermal-electrolyzer (PV/T-E) systems are limited.

In this study, electrical-thermal energy and hydrogen production from a small-scale PV/T-E hybrid power system was investigated. A numerical model was developed in Matlab/Simulink environment to evaluate the thermodynamic performance of different input variables, and each numerical model of the system was validated experimentally. The electrical and thermal efficiency and energy-exergy efficiency of the system were analyzed for the varying value of solar radiation and ambient temperatures.

In addition, techno-economic analysis of the PV/T-E system was conducted, and the hydrogen production cost was calculated using the life-cycle cost (LCC) method. The hydrogen cost of systems driven by $\mathrm{PV}$ and PV/T were also calculated in order to compare the two different technologies.

\section{Materials and Methods}

\subsection{System Design}

The experimental system built in Balikesir, Turkey ( $\left.39^{\circ} 39^{\prime} 11.873^{\prime \prime} \mathrm{N} 27^{\circ} 53^{\prime} 25.231^{\prime \prime} \mathrm{E}\right)$, consisted of two flat-plate PV/T panels with a tilt angle of 30 degrees and a PEM electrolyzer. The experiment period 
included was between June 2017 and September 2018. The PV/T array $(1.64 \times 1.74)$ was composed of 72 cells and the output power of each PV/T was $200 \mathrm{~W}$ with a 36.8 maximum power point voltage and 5.43 maximum power point current. A water pump was used to circulate water to remove the heat from the panel and protect it from excessive heat. The commercial PEM electrolyzer system was used to produce hydrogen. The electrolyzer had a capacity of $18 \mathrm{Nm}^{3} /$ day of $\mathrm{H}_{2}$ production at process pressure without a compressor. A step-down DC/DC converter was used to decrease the voltage level of the PV/T to provide the power input of the PEM electrolyzer. The higher voltage output achieved by the PV/T was reduced and applied to the electrolysis cell. The DC/DC converter had high efficiency and its efficiency was regarded as $98 \%$ in the numeric model. The simulation of the system was obtained using the Matlab/Simulink environment. The PV/T electrolyzer system consists of the following major components: a PV/T array, a DC/DC step-down converter, and a PEM electrolyzer system. The schematic diagram of the system is given in Figure 1.

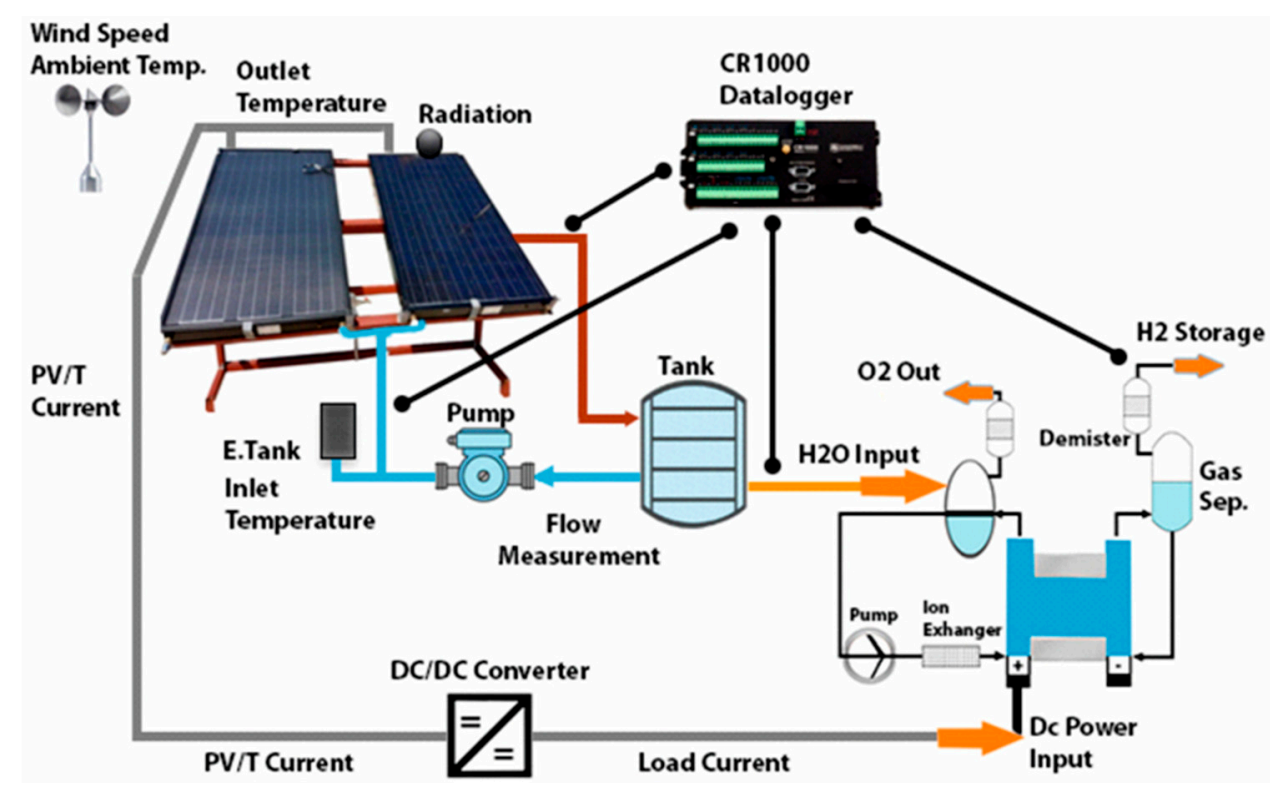

Figure 1. Schematic diagram of the proposed system.

A commercial PV/T (Solimpeks ${ }^{\circledR}$ Powertherm) was used in the system and the features of the $\mathrm{PV} / \mathrm{T}$ are given in the Table 1.

Table 1. Features of photovoltaic/thermal (PV/T) panel.

\begin{tabular}{|c|c|}
\hline Dimensions & $1640 \times 870 \times 105 \mathrm{~mm}$ \\
\hline Maximum current (A) & 5.43 \\
\hline Short circuit current (A) & 5.67 \\
\hline Maximum voltage $(\mathrm{V})$ & 36.8 \\
\hline Open circuit voltage (V) & 45.43 \\
\hline Glass & Extra Solar Glass \\
\hline Cell number & 72 \\
\hline Type & Monocrystal \\
\hline Thermal power $(\mathrm{W})$ & 680 \\
\hline Active cell area $\left(\mathrm{m}^{2}\right)$ & 1.222 \\
\hline
\end{tabular}

A data logger (Campbell Scientific CR1000) was used to record the data with the desired time periods and accuracy. The CR1000 datalogger has 16 analog single-ended inputs (8 differentials), and the measurements were recorded at desired intervals with the help of connected sensors. The thermocouples (PT100 and J type) were used for measuring the ambient, cell, fluid inlet, and outlet temperatures. The cell temperature of the PV/T was measured from the front surface by a type 
thermocouple. A pyranometer (Kipp and Zonen CMP11 model) was used to measure the incident solar radiation. The water flow rate was calculated with a flow meter (LZB 15 SL (0-250 L/h)). The output current was measured with a current sensor (ACS712). Each device in the measurement system is given in Table 2.

Table 2. Properties of measuring components.

\begin{tabular}{cccc}
\hline Material & Feature & Measured Variable & Accuracy \\
\hline Pyranometer & Kipp and Zonen CMP11 & Global irradiance & $\pm 2 \%$ \\
Anemometer & NRG 40 & Wind speed & $\pm 1 \%$ \\
Temperature sensor & PT100, J type & Ambient \& collector & $\pm 0.8 \%$ \\
Current Sensor & ASC712 (0-75 A) & Current & $\pm 0.15 \%$ \\
Flowmeter & LZB-15 SL $(0-250 \mathrm{~L} / \mathrm{h})$ & Mass flow rate & $\pm 1.5 \%$ \\
\hline
\end{tabular}

\subsection{Mathematical Model of the System}

Hybrid power systems need to be analyzed using highly complex numerical models for each part of the system, separately. The meteorological input values such as hourly based temperature and solar radiation data are required in the calculations of solar energy systems. It is quite complicated and time-consuming to perform analyses such as energy and exergy efficiencies when they are processed annually $(8760 \mathrm{~h})$. Thus, the calculation and the implementation of each element were simulated in the Matlab/Simulink environment. Simulink is mostly used for the analysis and optimization of electrical circuits and the field of control systems; however, it is rarely used for the thermodynamical modeling of solar energy systems. Dynamic models can be simulated quickly and with great flexibility [56].

The Simulink model contains quantitative phrases of the PV/T hybrid system. The output variables such as thermal and electrical efficiency, energy-exergy amounts, etc., are computed based on meteorological input data. Several blocks are provided to compute variables such as the collector flow rate, the fin factor, and heat losses. Hence, output variables can be computed hourly, daily, monthly, and yearly.

The PV/T one-dimensional steady-state model was modeled using Hottel-Whillier equations. Heat losses are considered in the thermal performance calculations of the PV/T system, and they depend on variables such as solar radiation intensity, wind speed, ambient temperature, the structure of the collector, transparent covering properties, radiation emissions and absorption value of the absorber surface, thermal conductivity coefficient, thickness, and type of insulation material [57].

Steady state thermal efficiency of PV/T collectors $\left(\eta_{\text {th }}\right)$ :

$$
\begin{gathered}
\eta_{t h}=\frac{Q_{u}}{I_{T}} \\
Q_{u}=A_{c} F_{R}\left[S-U_{L}\left(T_{i n}-T_{a}\right)\right]
\end{gathered}
$$

Total heat losses including the bottom, top and edge surfaces of the collector are calculated with Equation (3).

$$
U_{L}=U_{t}+U_{b}+U_{e}
$$

The collector flow rate factor is $F_{R}$ :

$$
F_{R}=\frac{\dot{\mathrm{m}} C_{p}}{A_{c} U_{L}}\left[1-e^{-\frac{A_{c} U_{L} F^{\prime}}{\dot{m} C_{p}}}\right]
$$

The collector efficiency factor is $F^{\prime}$ :

$$
F^{\prime}=\frac{\frac{1}{U_{L}}}{W\left[\frac{1}{U_{L}[D+(W-D) F]}+\frac{1}{W \cdot h_{P V A}}+\frac{1}{\pi D h_{f i}}\right]}
$$


$F$ is the fin factor:

$$
F=\frac{\tanh \left(\tanh \left(M \frac{W-D_{0}}{2}\right)\right)}{\left(M \frac{W-D_{0}}{2}\right)}
$$

The thermal efficiency expression can be found with the equation given in Equation (7):

$$
\eta_{t h}=F_{R}\left(\alpha_{g} \tau\right)-F_{R} U_{L} \frac{T_{a}-T_{\text {in }}}{I_{T}}
$$

$T_{\mathrm{pm}}$ is average temperature of the absorber plate. It is also used for the electrical output and efficiency calculation and is given in Equation (8).

$$
T_{p m}=T_{i n}+\left(\frac{Q_{u} / A_{c}}{U_{L} F_{R}}\right)\left(1-F_{R}\right)
$$

The electrical efficiency changes with the PV temperature and is calculated with Equation (9). $\left(\beta_{0}=0.0045\right)[58]$ :

$$
\eta_{e}=\eta_{0}\left[1-\beta_{0}\left(T_{p m}-T_{r e f}\right)\right]
$$

The electrical output of the system is given in Equation (10):

$$
P_{e}=\eta_{e} \cdot A_{c} \cdot I_{T}
$$

Exergy analysis of the PV/T system is based on the second law of thermodynamics where the general exergy balance is expressed in mean form, neglecting the effects arising from potential and kinetic energy variations [24].

$$
\begin{gathered}
\sum E x_{i n}-\sum E x_{o}=\sum E x_{d} \\
\sum E x_{i n}-\sum\left(E x_{t h}+E x_{e}\right)=\sum E x_{d}
\end{gathered}
$$

The temperature of the sun $\left(T_{\mathrm{s}}\right)$ is taken as $5778 \mathrm{~K}$ and exergy input $\left(E x_{i n}\right)$ can be calculated by Equation (13):

$$
E x_{i n}=A_{c} \cdot I_{T} \cdot\left[1-\frac{4}{3}\left(\frac{T_{a}}{T_{s}}\right)+\frac{1}{3}\left(\frac{T_{a}}{T_{s}}\right)^{4}\right]
$$

Thermal exergy is expressed with Equation (14):

$$
E x_{t h}=Q_{u} \cdot\left[1-\left(\frac{T_{a}+273}{T_{o}+273}\right)\right]
$$

Electrical exergy:

$$
E x_{e}=\eta_{e} \cdot A_{c} \cdot I_{T} \cdot\left[1-\frac{4}{3}\left(\frac{T_{a}}{T_{s}}\right)+\frac{1}{3}\left(\frac{T_{a}}{T_{s}}\right)^{4}\right]
$$

The total PV/T exergy equals the sum of the electrical exergy and thermal exergy:

$$
E x_{t}=E x_{t h}+E x_{e}
$$

The simulation parameters of PV/T, which were used in the numerical model, were given in the Table 3. 
Table 3. Simulation parameters for the PV/T used in the numeric model.

\begin{tabular}{cc}
\hline Symbols-Parameters & Values \\
\hline Diameter of the copper tube $(\mathrm{D})$ & $0.01 \mathrm{~m}$ \\
Width of the tube spacing $(\mathrm{W})$ & $0.092 \mathrm{~m}$ \\
PV thermal conductivity $\left(\mathrm{k}_{\mathrm{pv}}\right)$ & $149 \mathrm{~W} / \mathrm{m} \mathrm{K}$ \\
PV laminate thickness $\left(\mathrm{l}_{\mathrm{pv}}\right)$ & $0.0002 \mathrm{~m}$ \\
Absorber thermal conductivity $\left(\mathrm{k}_{\mathrm{abs}}\right)$ & $385 \mathrm{~W} / \mathrm{m} \mathrm{K}$ \\
Absorber laminate thickness $\left(\mathrm{l}_{\mathrm{abs}}\right)$ & $0.00012 \mathrm{~m}$ \\
Insulation material thermal conductivity $\left(\mathrm{k}_{\mathrm{i}}\right)$ & $0.04 \mathrm{~W} / \mathrm{m} \mathrm{K}$ \\
Insulation material thickness $\left(\mathrm{l}_{\mathrm{i}}\right)$ & $0.05 \mathrm{~m}$ \\
Transmission-absorption coefficient $\left(\tau \alpha_{\mathrm{g}}\right)$ & $0.8 \mathrm{~W} / \mathrm{m} \mathrm{K}$ \\
\hline
\end{tabular}

\subsection{PEM Mathematical Model}

The energy for the PEM electrolyzer is composed of two parts: the change of thermal energy $(T \Delta S)$ and the change in Gibbs free energy $(\Delta G)$. At standard pressure and temperature, the Gibbs free energy value is defined as a zero-energy point and is used to calculate the change in the energy of a system. Equation (17) is given as:

$$
\Delta H=\Delta G-T . \Delta S
$$

where $\Delta H$ is the enthalpy change of water splitting and $T$ and $\Delta S$ stand for the water-splitting temperature and entropy change, respectively [59].

In order to model the dynamic behavior of a PEM electrolyzer precisely, it is necessary to understand the anode, cathode, membrane, voltage sections and their interactions with each other. The reversible potential of water splitting can be calculated with Equation (18) [60]:

$$
E_{0}=-\frac{\Delta G^{0}}{z F}
$$

where the $F$ is the Faraday constant and $\mathrm{z}$ is the number of electrons transferred. The voltage of the electrolyzer $\left(V_{\text {elc }}\right)$ can be calculated as follows:

$$
V_{\text {elc }}=E_{r}+V_{a c t, a}+V_{a c t, c}+V_{\text {ohm }}
$$

where $E_{r}$ refers the ideal supplied electrical potential. $V_{\text {act a,c }}$ and $V_{\mathrm{ohm}}$ are the anode-cathode, activation and ohmic losses, respectively.

The ideal electrical potential for water can be calculated by the Nernst equation which is as follows [61]:

$$
E_{r}=1.482-0.000845 \cdot T+4.31 \times 10^{-5} \cdot T \cdot e^{\left(p_{H 2} \cdot \sqrt{\left.P_{\mathrm{O} 2}\right)}\right.}
$$

where $T$ is the operating temperature of the PEM electrolyzer. $p_{\mathrm{H} 2}$ and $p_{\mathrm{O} 2}$ show the partial pressures of the hydrogen and oxygen, respectively.

Energy barriers that must react to reactive reactants are known as activation energy, which is a result of activation overvoltage. The activation overpotential represents the activity of the electrodes in the electrochemical reaction, and it is given with the Butler-Volmer equation:

$$
\begin{aligned}
\eta_{A} & =\frac{R \cdot T}{\alpha_{a} \cdot z \cdot F} \ln \left(\frac{i}{i_{0, a}}\right) \\
\eta_{c} & =\frac{R \cdot T}{\alpha_{c} \cdot z \cdot F} \ln \left(\frac{i}{i_{o, c}}\right)
\end{aligned}
$$

$\alpha_{a}$ and $\alpha_{c}$ are transfer coefficient of anode and cathode, $i_{\mathrm{a}}$ and $i_{\mathrm{c}}$ are the exchange current density of the anode and cathode, and $i$ is current density. 
Ohmic losses occur as a result of the movement of ions in the solid electrolyte and the flow of electrons through the electrodes. Ohmic overpotential across the PEM is inversely related to the local ionic conductivity and it is empirically given as

$$
\begin{gathered}
V_{\text {ohm }}=\frac{\phi}{\sigma} \cdot i \\
\sigma=\left(0.00514 . \lambda_{m}-0.00326\right) \cdot \exp \left(1268 .\left(\frac{1}{303}-\frac{1}{T}\right)\right)
\end{gathered}
$$

where $i$ current density, $\sigma$ conductivity and $\lambda_{m}$ the thickness of the membrane.

The efficiency of the PEM electrolyzer is given in Equation (25) [62]:

$$
\eta_{e n}=\frac{L H V \cdot \dot{\mathrm{m}}_{\mathrm{H}_{2} \mathrm{O}}}{W_{\text {elc }}}
$$

Exergy efficiency is calculated as the ratio of the exergy difference of reactants $\left(\mathrm{H}_{2} \mathrm{O}\right)$ reacting with the exergy of the products exiting the reaction to the input electrical power of the PEM electrolyzer [63].

$$
\eta_{e x}=\frac{(E x)_{P}-(E x)_{r}}{P_{e, i n}}=\frac{\left(\dot{\mathrm{E}}_{H_{2}, p}+\dot{\mathrm{E}}_{\mathrm{O}_{2, p}}\right)-\left(\dot{\mathrm{E}}_{\mathrm{H}_{2} \mathrm{O}, r}\right)}{P_{e, \text { in }}}
$$

The total exergy transfer of reactants and products per unit mass is the sum of physical and chemical exergy:

$$
\mathrm{Ex}=\mathrm{ex}_{\mathrm{ph}}+\mathrm{ex}_{\mathrm{ch}}
$$

where the chemical exergy of hydrogen is $159,138 \mathrm{~kJ} \mathrm{~kg}^{-1}$, water is $2.5 \mathrm{~kJ} \mathrm{~kg}^{-1}$ and oxygen is 0 . The physical exergy calculation is given in Equation (28) [64]:

$$
E x_{p h}=\left(h-h_{0}\right)-T_{0} \cdot\left(s-s_{0}\right)
$$

where $C_{\mathrm{p}}$ is specific heat and $\mathrm{k}$ is specific heat rate. The physical exergy is given in Equation (29) [63]:

$$
E x_{p h}=C_{p} \cdot T_{0} \cdot\left[\frac{T}{T_{0}}-1-\ln \left(\frac{T}{T_{0}}\right)+\ln \left(\frac{P}{P_{0}}\right)^{(k-1) / k}\right]
$$

The total exergy rate of products and reactants can be calculated individually as follows:

$$
\begin{gathered}
\dot{\mathrm{E}}_{\mathrm{H}_{2} \mathrm{O}, r}=\dot{\mathrm{m}}_{\mathrm{H}_{2} \mathrm{O}, \mathrm{r}} \cdot\left(e x_{c h}+e x_{p h}\right)_{\mathrm{H}_{2} \mathrm{O}, r} \\
\dot{\mathrm{E}}_{\mathrm{H}_{2}}=\dot{\mathrm{m}}_{\mathrm{H}_{2}, p} \cdot\left(e x_{c h}+e x_{p h}\right)_{\mathrm{H}_{2, p}} \\
\dot{\mathrm{E}}_{\mathrm{O}_{2, p}}=\dot{\mathrm{m}}_{\mathrm{O}_{2, p},} \cdot\left(e x_{c h}+e x_{p h}\right)_{\mathrm{O}_{2, p}}
\end{gathered}
$$

The simulation parameters of PEM electrolyzer which are used in the numerical model, were given in the Table 4. 
Table 4. Simulation parameters for the PEM electrolyzer used in the numeric model.

\begin{tabular}{cc}
\hline Symbols-Parameters & Values \\
\hline Transfer coefficient anode-cathode $(\alpha \mathrm{a}, \alpha \mathrm{c})$ & 0.5 \\
Anode-cathode electrode thickness $(\delta \mathrm{a}, \delta \mathrm{c})$ & $5 \times 10^{-6} \mathrm{~m}$ \\
Anode exchange current densities $\left(\mathrm{i}_{0}, \mathrm{a}\right)$ & $0.0042 \mathrm{~A} / \mathrm{cm}^{2}$ \\
Cathode exchange current density $\left(\mathrm{i}_{0, \mathrm{c}}\right)$ & $0.001 \mathrm{~A} / \mathrm{cm}^{2}$ \\
Current density $(\mathrm{i})$ & $1.6 \mathrm{~A} / \mathrm{cm}^{2}$ \\
Operating pressure $(\mathrm{P})$ & $1 \mathrm{bar}$ \\
Faraday number $(\mathrm{F})$ & $96,485.3 \mathrm{~A} / \mathrm{mol}$ \\
Operating temperature $(\mathrm{T})$ & $303 \mathrm{~K}$ \\
Degree of humidification $(\lambda)$ & 24 \\
\hline
\end{tabular}

\subsection{Economic Analysis}

The LCC (life-cycle cost) method, which is used to compare the energy costs of technologies with different cost structures, is preferred for the economic analysis. The analysis attempts to calculate the cost of delivering a service during the whole period of the project, rather than comparing only the initial capital costs or operating costs. All of the costs (capital cost (CC), operating and maintenance costs (OMC), and repair and replacement costs (RRC)) that will occur during the system lifetime are considered based on the time value of money [65].

$$
T P V=\text { Initial cost }+\sum O \& M+\sum \text { Replacement }
$$

The real discount rate $\left(R^{\prime}\right)$ and the capital recovery factor $(C R F)$ is defined as follows:

$$
R^{\prime}=\frac{i^{\prime}-f}{1+f}
$$

where $i^{\prime}$ is the nominal discount rate and $f$ is the inflation rate;

$$
C R F=\frac{\left(1+R^{\prime}\right)^{N} \cdot R^{\prime}}{\left(1+R^{\prime}\right)^{N}-1}
$$

The final cost of hydrogen is defined as

$$
\operatorname{Cost}\left(\frac{\$}{k g H_{2}}\right)=\frac{T P V \cdot C R F}{\text { Annual } H_{2} \text { production }}
$$

The major economic assumptions determining the costs are as follows:

- The economic evaluation (N) period is 25 years for the PV/T panels, the DC/DC converter, and the storage systems, and is 15 years for the PEM electrolyzer.

- The economic indicators of nominal discount rate and inflation rate were used as $9 \%$ and $12 \%$, respectively, for 2017 [66].

- The installation, operation and maintenance are not included in cost calculation.

- The capital costs per watt for the PV, the PV/T, and the PEM electrolyzer were taken as $0.82,2$, and $0.9 \mathrm{USD} / \mathrm{W}$, respectively.

\section{Results}

In this study, the hourly meteorological data used in the simulation such as ambient temperature and inclined solar radiation were measured and stored by the data logger between the dates of 10/08/2017 and 31/07/2018. In order to perform verification between the numerical model and experimental system, the electrical and thermal energy and exergy efficiencies and hydrogen production were calculated 
using actual hourly measurement data for the specified dates (01.09.2017-15.09.2017), which are given in Figure 2. The measured radiation and ambient temperature data changed between $0-980.2 \mathrm{~W} / \mathrm{m}^{2}$ and $11.2-37.9^{\circ} \mathrm{C}$, respectively.

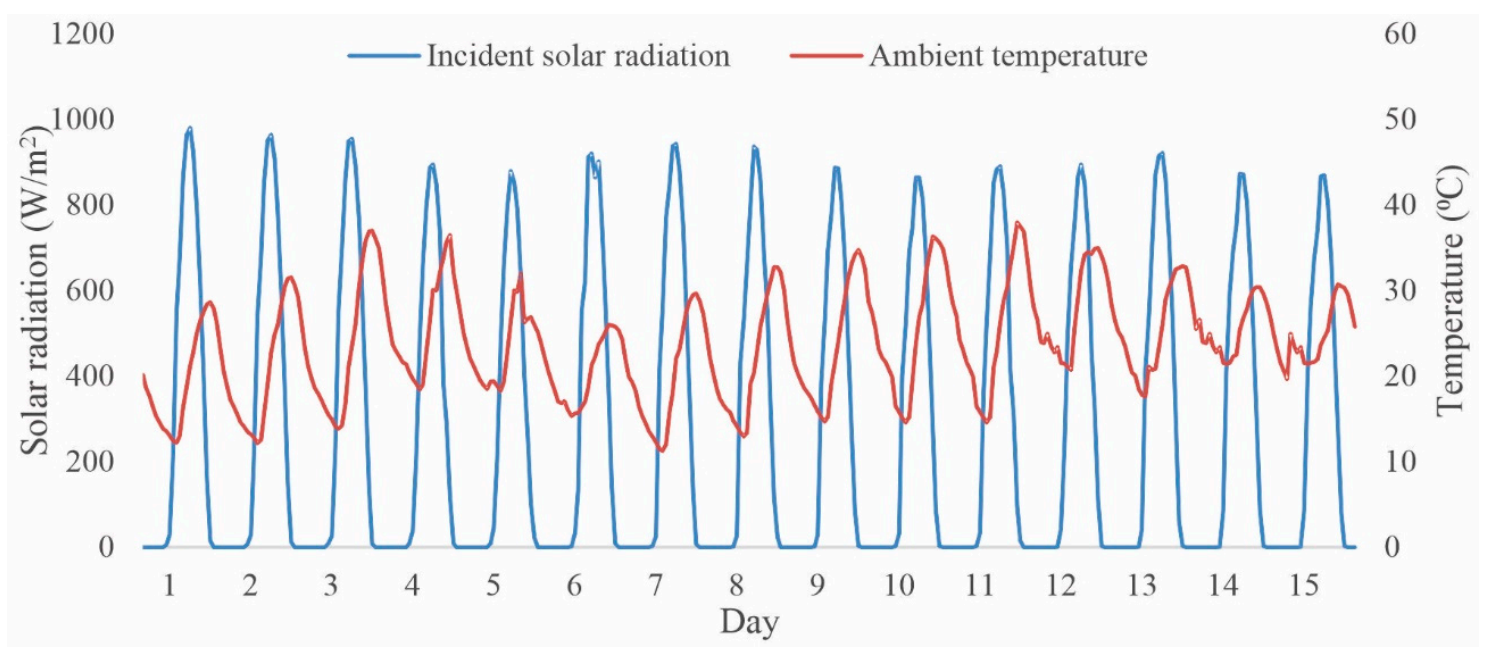

Figure 2. Variation of the incident solar radiation and ambient temperature.

The monthly average energy and exergy inputs are shown in Figure 3. The energy and exergy distributions have similar trends and vary between $2.72-8.38 \mathrm{~kW} / \mathrm{m}^{2}$ and $2.54-7.8 \mathrm{~kW} / \mathrm{m}^{2}$, respectively.

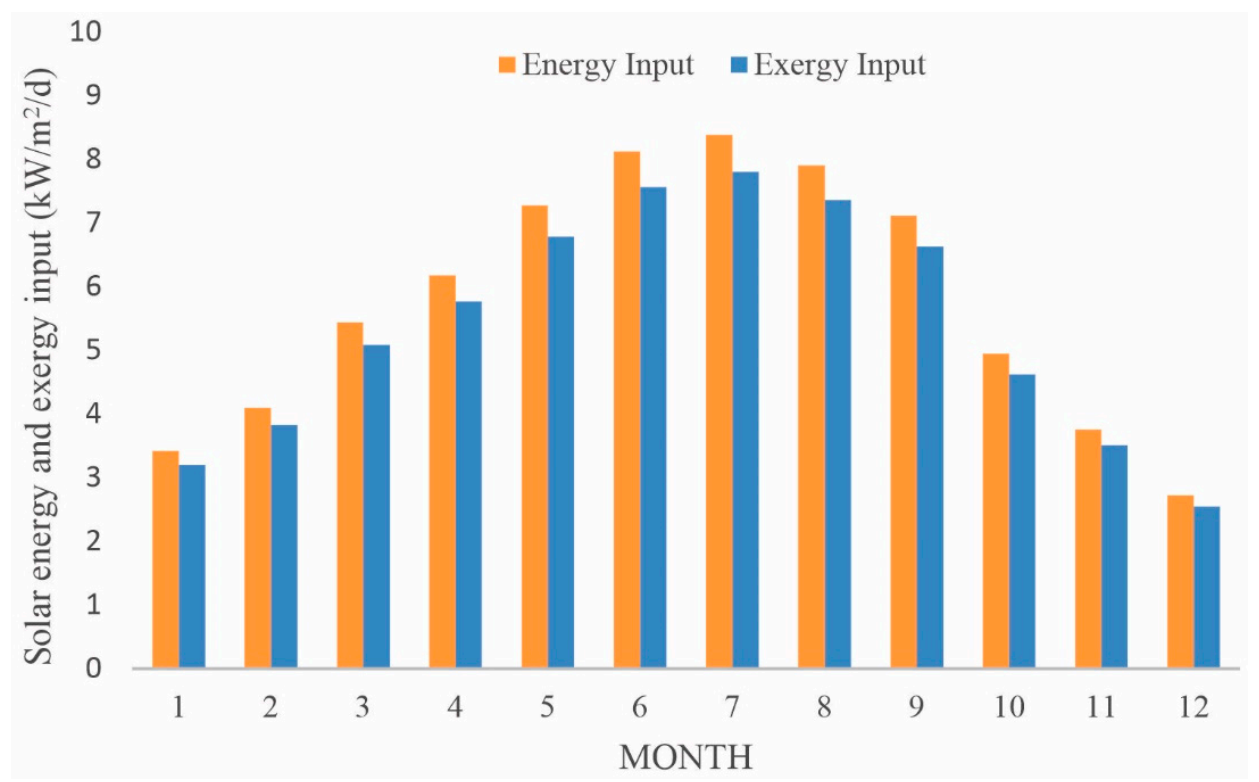

Figure 3. Monthly average solar energy and exergy input for PV/T.

The annual amount of electrical, thermal, and hydrogen production by the PV/T-E hybrid system in Balikesir were calculated with the numerical model and the results were $556.8 \mathrm{kWh}, 1912 \mathrm{kWh}$ and $4.491 \mathrm{~kg} /$ year, respectively. The monthly amount of the electrical and thermal energy and produced hydrogen are given in Figure 4. 


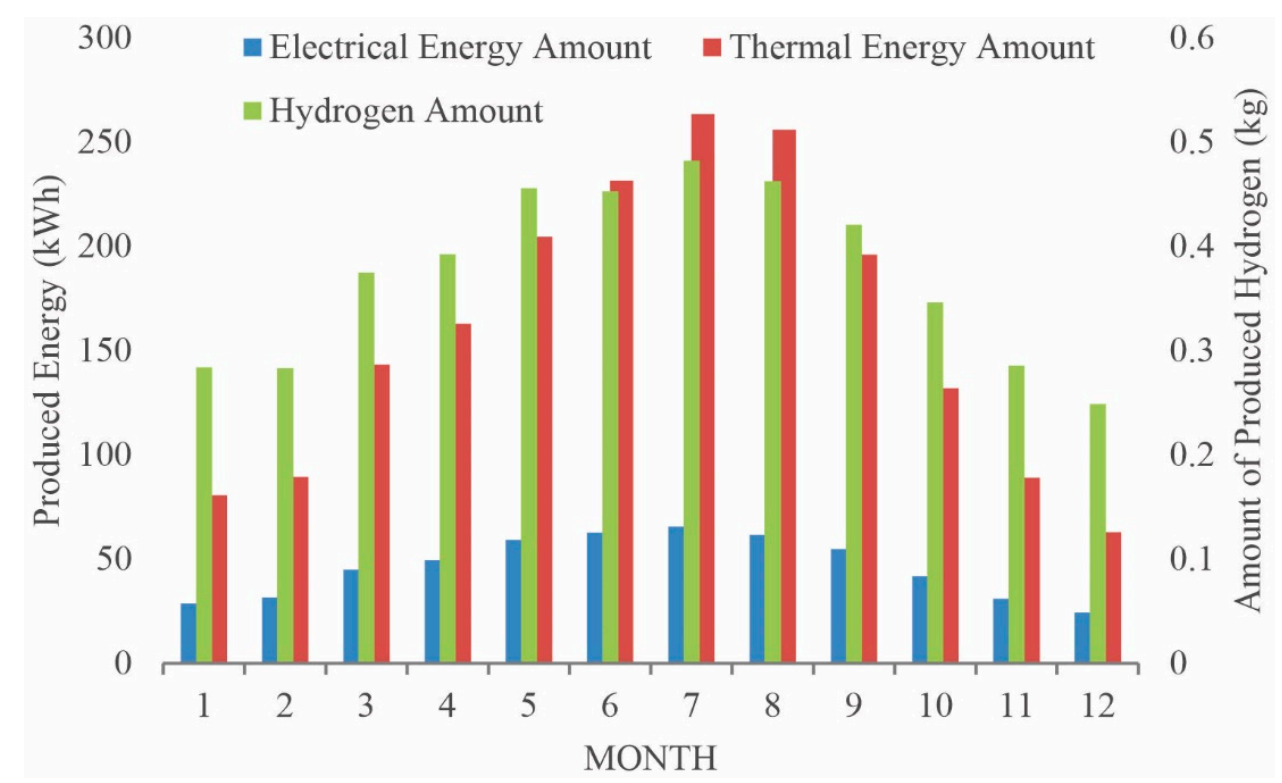

Figure 4. Monthly distribution of electrical-thermal energy and produced hydrogen amounts.

The experimental PV/T array current-voltage (I-V) and power-voltage (P-V) characteristic for $950 \mathrm{~W} / \mathrm{m}^{2}$ solar radiation and $33^{\circ} \mathrm{C}$ ambient temperature is presented in Figure $5 \mathrm{a}$. The short circuit current of the array and the open-circuit voltage were measured as $4.96 \mathrm{~A}$ and $39.9 \mathrm{~V}$ under these conditions, respectively. Hence, the maximum electrical output of the array was calculated as $139 \mathrm{~W}$ with $32 \mathrm{~V}$. The characteristic experimental thermal efficiency depending on $\left(\mathrm{T}_{\mathrm{in}}-\mathrm{T}_{\mathrm{a}}\right) / \mathrm{I}_{\mathrm{T}}$ was calculated on a daily basis and compared with the simulation data under the same climatic conditions (Figure $5 b$ ). The optical efficiency of the experimental system was obtained as $45.8 \%$, and it was $47.9 \%$ for the simulation system.

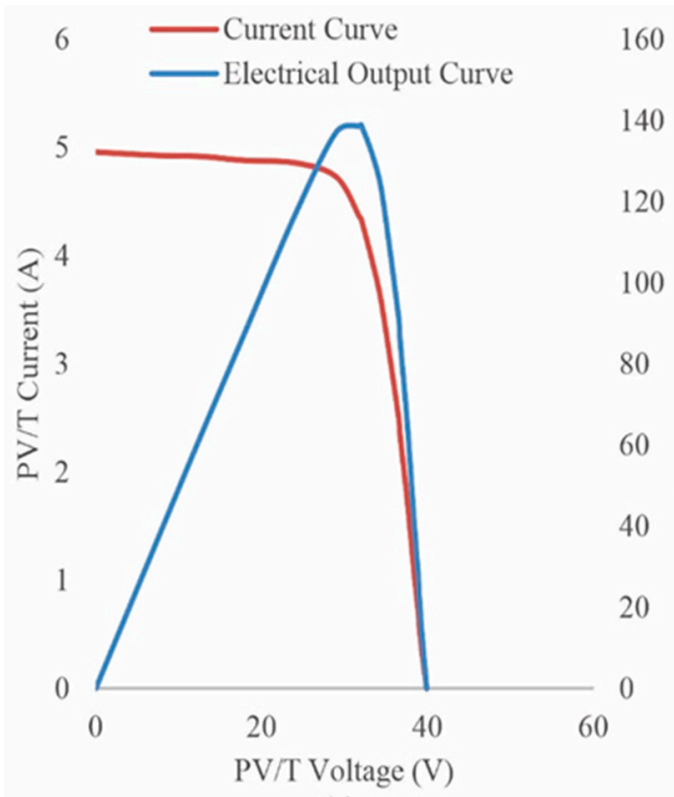

(a)

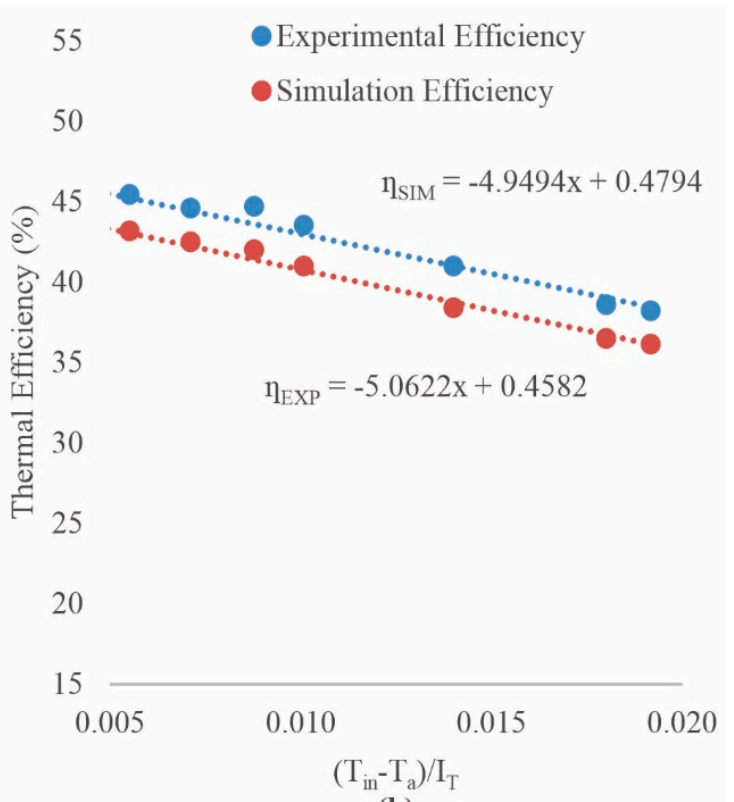

(b)

Figure 5. Current-voltage (I-V) and power-voltage (P-V) curve of the PV/T system (a) comparison of experimental and simulation thermal efficiencies as a function of the ratio $\left(\mathrm{T}_{\mathrm{in}}-\mathrm{T}_{\mathrm{a}}\right) / \mathrm{I}_{\mathrm{T}}(\mathbf{b})$.

The energy and exergy efficiencies of the PV/T system dependent on solar energy and exergy input, ambient and outlet temperatures were calculated between the hours of 09:00 and 19:00 on 2nd of September and are given in Figure 6. While the ambient temperatures, solar energy, and exergy inputs 
varied in the ranges of $12.8-31.4^{\circ} \mathrm{C}, 187-1177 \mathrm{~W}$, and $173-1097 \mathrm{~W}$, respectively, the total energy and exergy efficiencies were calculated in the ranges of $35-60 \%$ and $13.7-15.8 \%$, respectively. The exergetic efficiency was less than the energy efficiency due to losses and exergy destructions in the system.

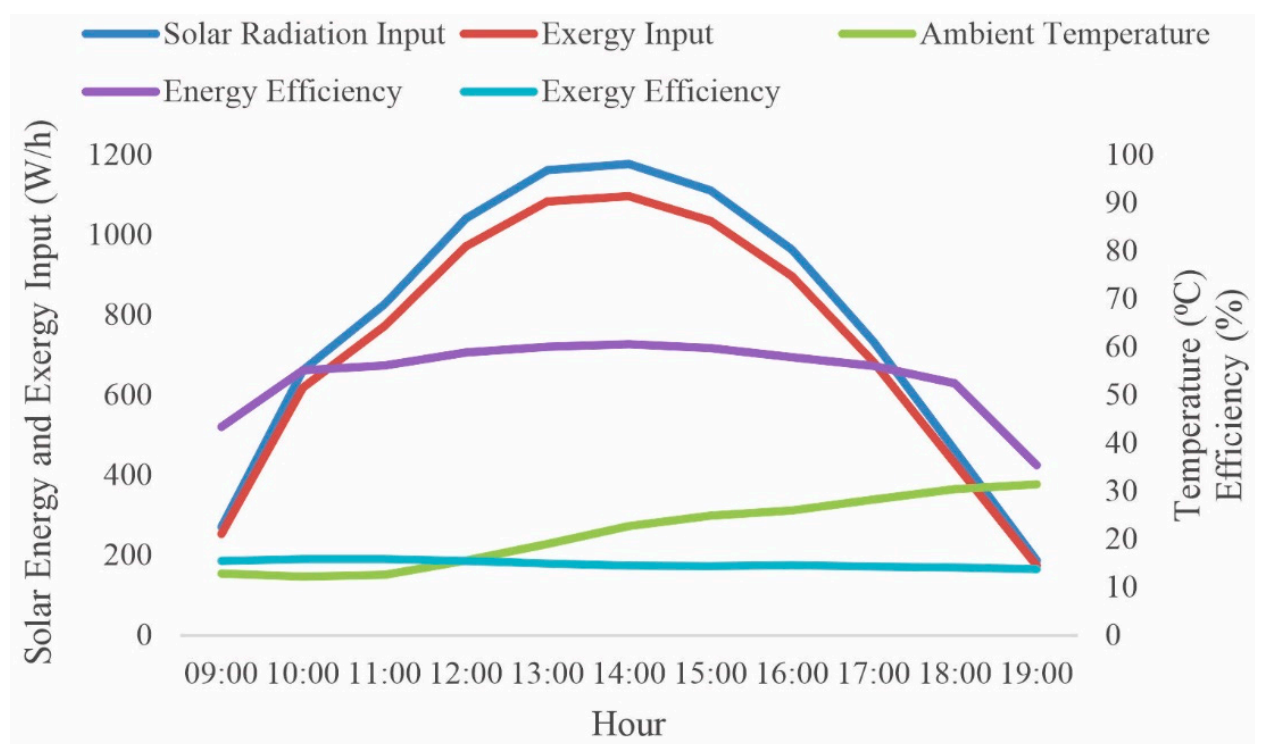

Figure 6. The hourly variation in the energy-exergy efficiency of the PV/T, energy-exergy input and ambient temperature on a daily basis.

The variations of the hourly electrical, thermal and total PV/T energy amounts depending on ambient temperature and inclined radiation on a daily basis are shown in Figure 7. While inclined radiation and ambient data varied in the respective ranges of $153-963 \mathrm{~W} / \mathrm{m}^{2}$ and $12.8-31.4{ }^{\circ} \mathrm{C}$, the $\mathrm{PV}$ temperature changed between $26.3^{\circ} \mathrm{C}$ and $50{ }^{\circ} \mathrm{C}$, and the produced electrical, thermal and total energy amounts were calculated as varying in the ranges of $24.75-156.4 \mathrm{Wh}, 41.5-558.7 \mathrm{Wh}$, and $66.25-713.6 \mathrm{Wh}$, respectively. The results showed that the increase in PV cell temperature led to a decrease in both PV efficiency and electrical output of the system.

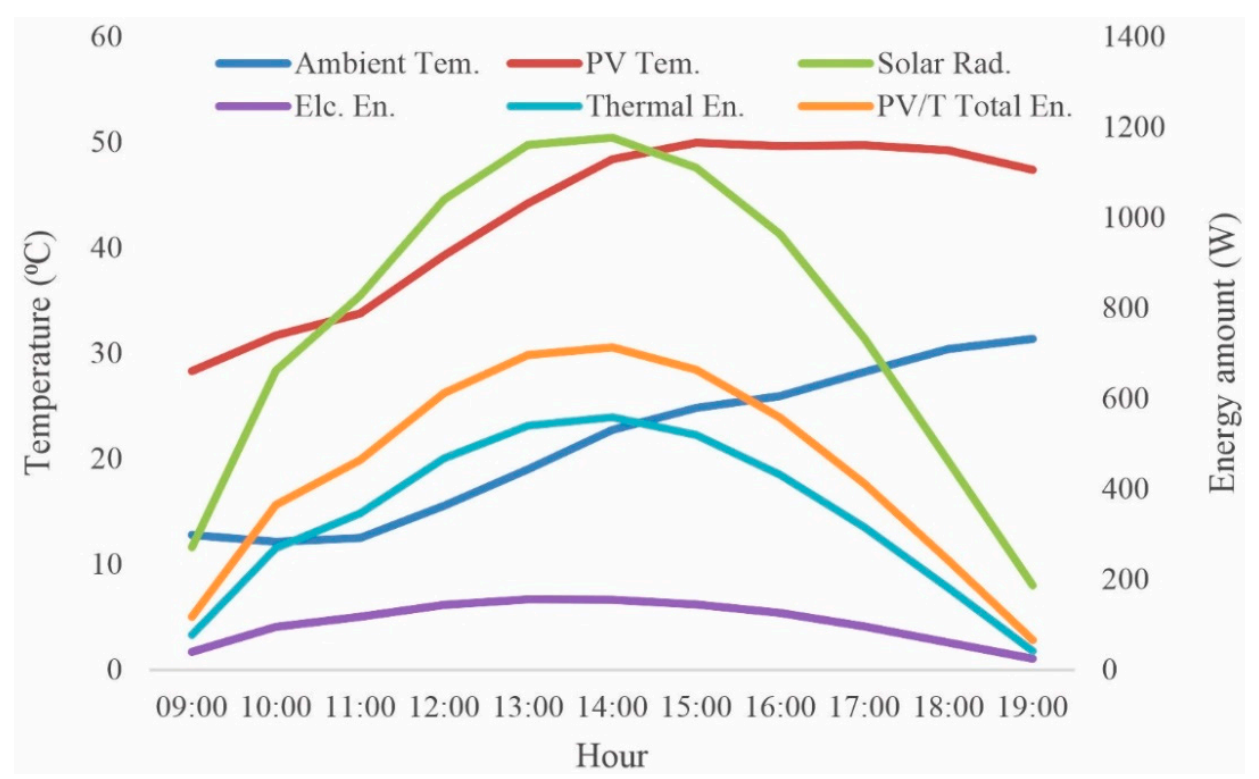

Figure 7. Variation of the PV/T collector energy production on a daily basis.

In this study, the electrochemical model of the PEM electrolyzer was implemented and verified with experimental results. As shown in Figure 8a, the change in the electrolysis overpotentials $\left(E_{\mathrm{r}}\right.$, 
$V_{\text {ohm }}, V_{\text {act }}$, and $\left.V_{\text {elc }}\right)$ under the $30^{\circ} \mathrm{C}$ operation temperature conditions correlated with the change in the current. The ohmic voltage increased proportionally to the current increase. The anode activation overpotential was calculated as $0.37 \mathrm{~V}$, while the cathode overpotential was $0.25 \mathrm{~V}$ for $1600 \mathrm{~mA} / \mathrm{cm}^{2}$. The change in the electrolysis voltage depending on the current and temperature was also investigated by changing the current and temperature in the respective ranges of $200-1600 \mathrm{~mA} / \mathrm{cm}^{2}$ and $30-65^{\circ} \mathrm{C}$. The variations in the electrolyzer voltage in relation to different levels of the current and temperature correlated well with the experimental results (Figure 8b). As shown in Figure 8c, the change in electrolyzer voltage was also investigated in relation to the PV/T's water supply and the current output between 12:00 and 18:00. The decrease in the current and increase in the water temperature caused the electrolyzer voltage to decrease.

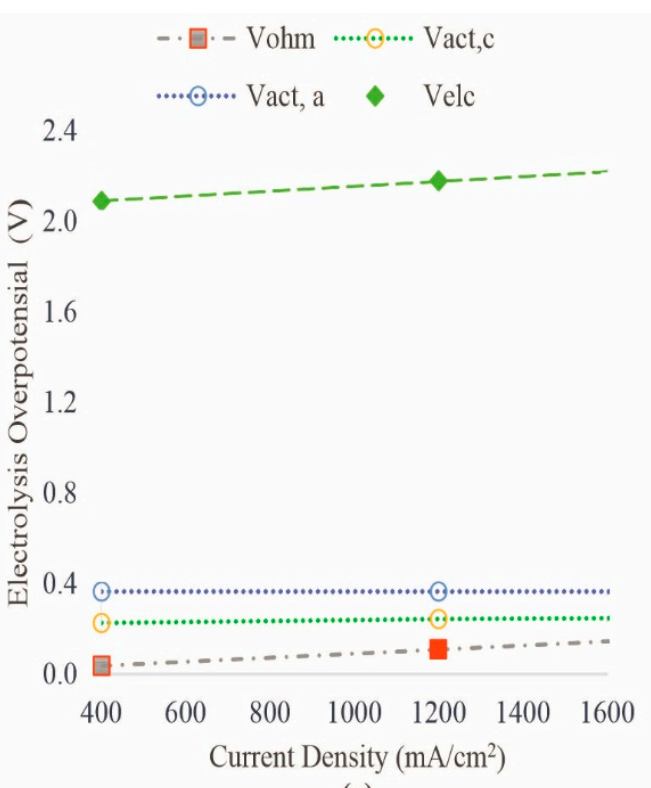

(a)

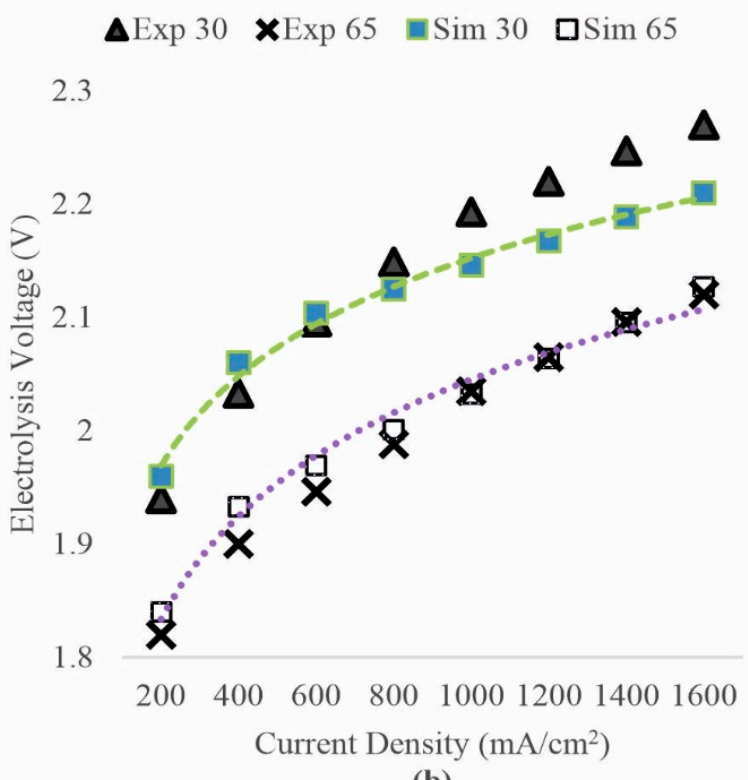

(b)

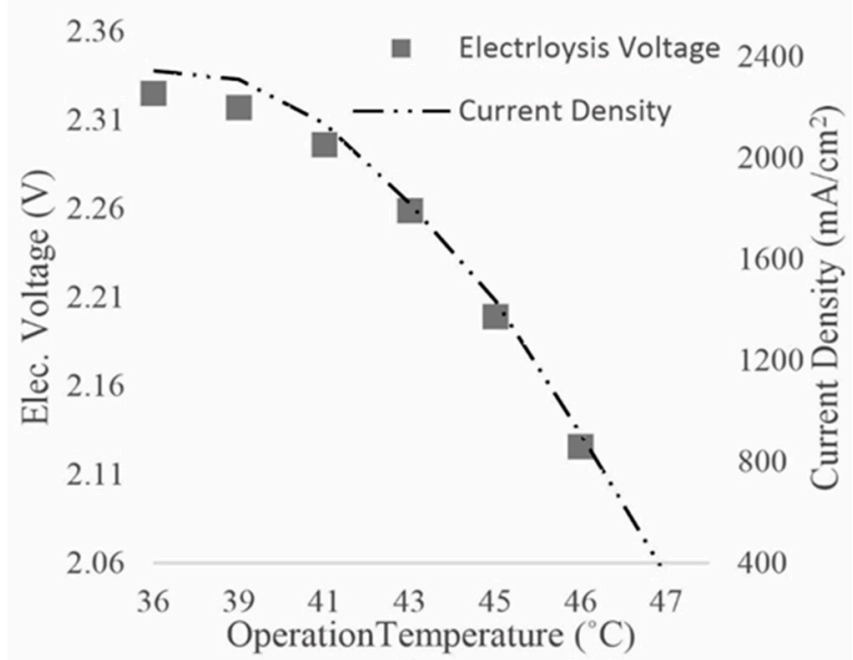

(c)

Figure 8. The variation of the PEM overpotentials (a) comparison of experimental and simulation system electrolyzer voltages with different water temperatures depending on the electrolyzer current (b) the variation in hourly electrolyzer voltage depending on the current and water temperature (c).

The hourly hydrogen production of the PEM electrolyzer and the electricity generation of the PV/T system were calculated on the 2nd September 2017. According to the calculations, $17.38 \mathrm{gr} / \mathrm{day}$ of $\mathrm{H}_{2}$ and 1147 Wh/day of electricity were produced with the PV/T-E system (Figure 9). 


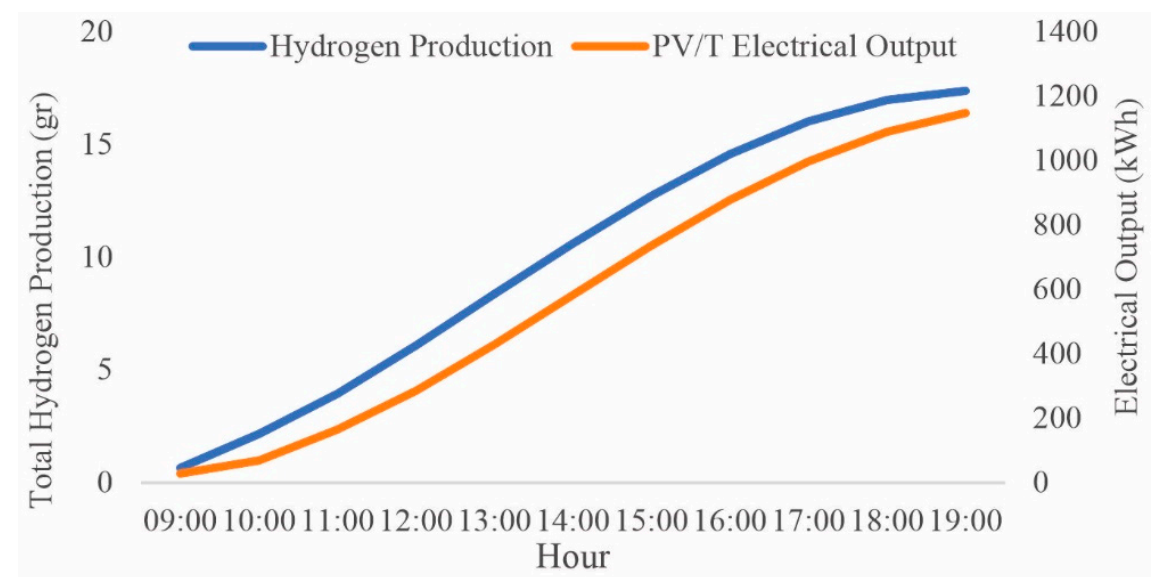

Figure 9. Electricity and hydrogen production of the system on 2nd September.

The daily variation in the energy and exergy efficiency of the PEM electrolyzer depending on the temperature of supplied water and the current from the PV/T system is shown in Figure 10. While the current density and the water temperature varied in the ranges of $400-2350 \mathrm{~mA} / \mathrm{cm}^{2}$ and $28.1-45.8{ }^{\circ} \mathrm{C}$, respectively, the energy and exergy efficiency changed between 57.7 and $69.59 \%$ and $54.3-60.7 \%$, respectively. The increase in the temperature of the supplied water and decrease in the current caused energy and exergy efficiencies to increase. It is clear that the exergy efficiency of the PEM electrolyzer is higher than the PV/T system's exergy efficiency. The reason is that the solar radiation has a large capacity for useful work (exergy) due to the high temperature of the Sun. The higher loss of exergy in the PV/T system was caused by irreversibility of the process. In comparison, the PEM electrolyzer exergy losses are around $40-45 \%$. This loss is the difference between the exergy entering the electrolyzer as an electrical energy, and the exergy exiting the electrolyzer in the form of the hydrogen produced in the process.

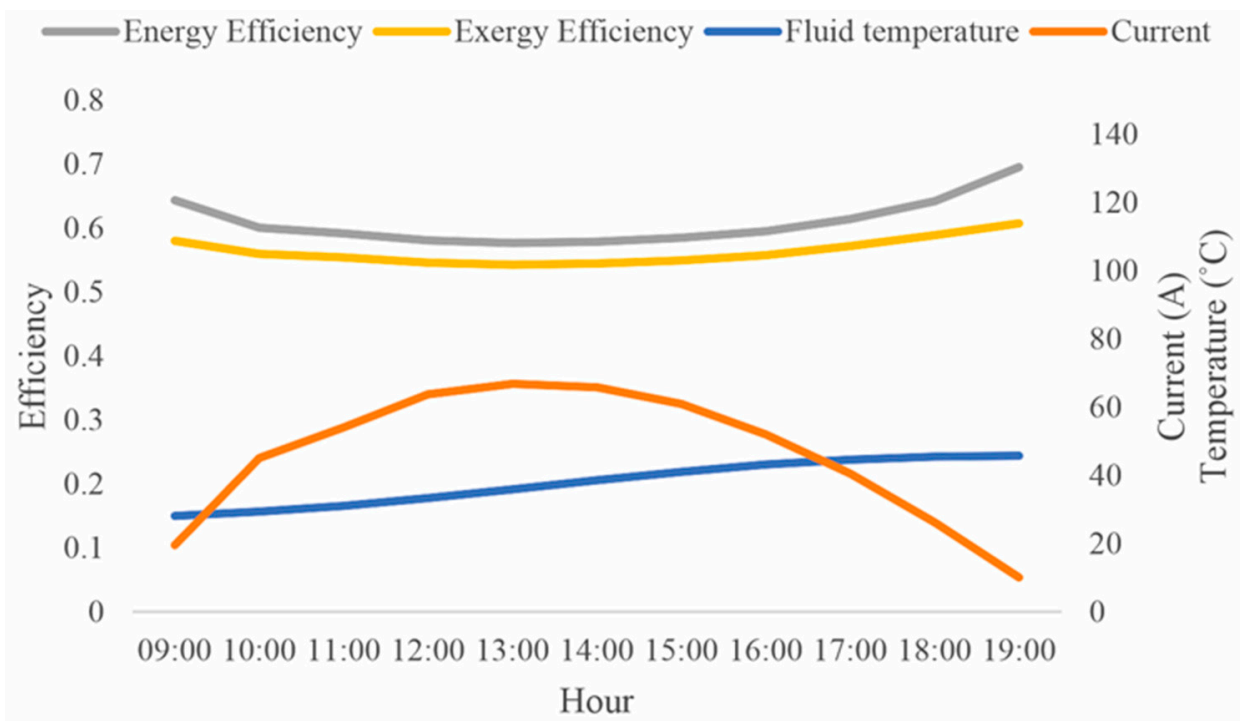

Figure 10. The hourly variation of energy-exergy efficiency of the PEM electrolyzer depending on the water temperature and current on 2nd September.

In order to determine the impact of a higher water temperature on annual hydrogen production, the monthly hydrogen production is calculated by examining a $65{ }^{\circ} \mathrm{C}$ operating temperature in comparison to the actual PV/T temperature under the same conditions (Figure 11). Thus, the annual hydrogen production amounts are $4.593 \mathrm{~kg}$ and $4.491 \mathrm{~kg}$, respectively. 


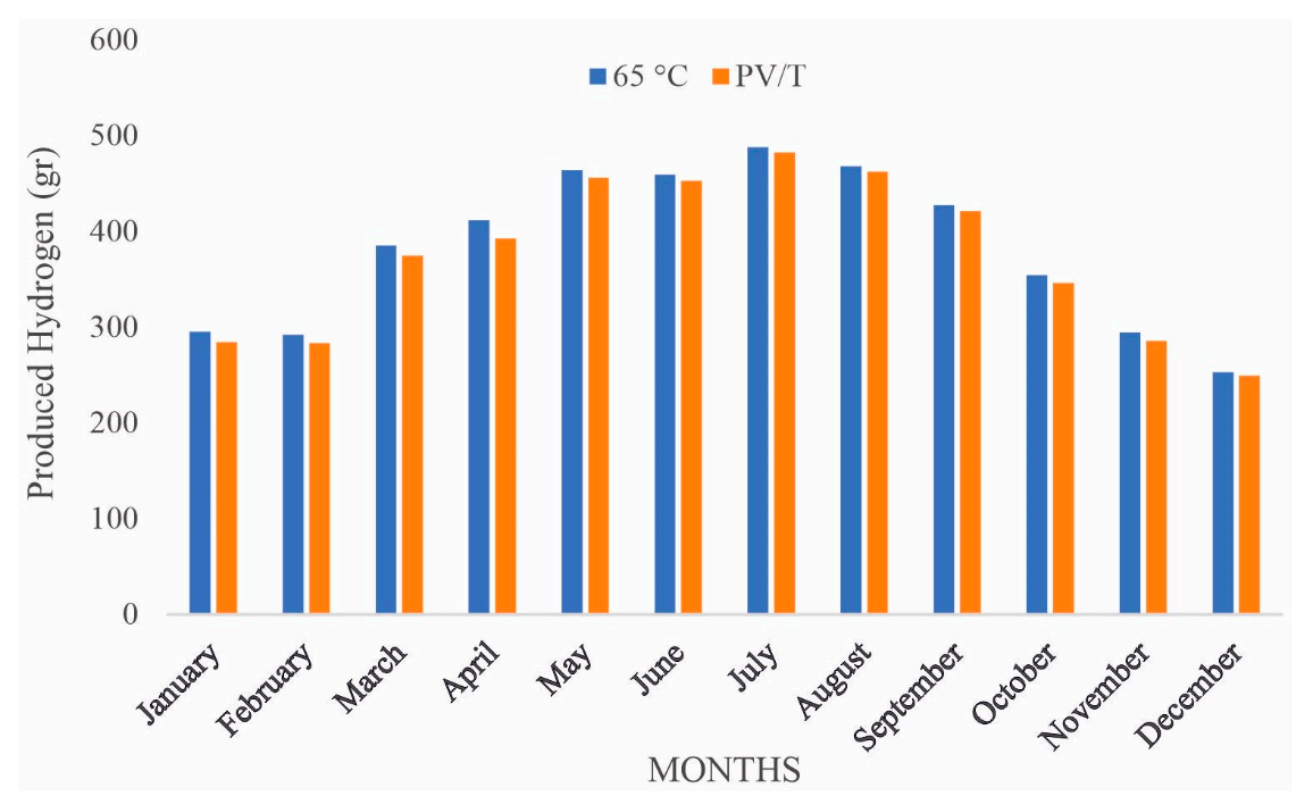

Figure 11. The annual hydrogen production amount calculated for $65{ }^{\circ} \mathrm{C}$ and actual PV/T water temperature.

In addition, a comparison of the hydrogen production performance of the PV/T PEM electrolyzer system with the PV-E system was conducted. The amount of monthly hydrogen was calculated by modeling the PV-E power system in the Hybrid optimization model for electric renewable (HOMER) simulation program with the same performance and meteorological input values as those used for the PV/T-PEM electrolyzer system. The analysis was conducted with the same values and under the same conditions in the HOMER simulation. As a result of the simulation, $3.96 \mathrm{~kg}$ of hydrogen was calculated annually for the PV system, while this value was $4.49 \mathrm{~kg}$ in the Matlab/Simulink for the PV/T system (Figure 12).

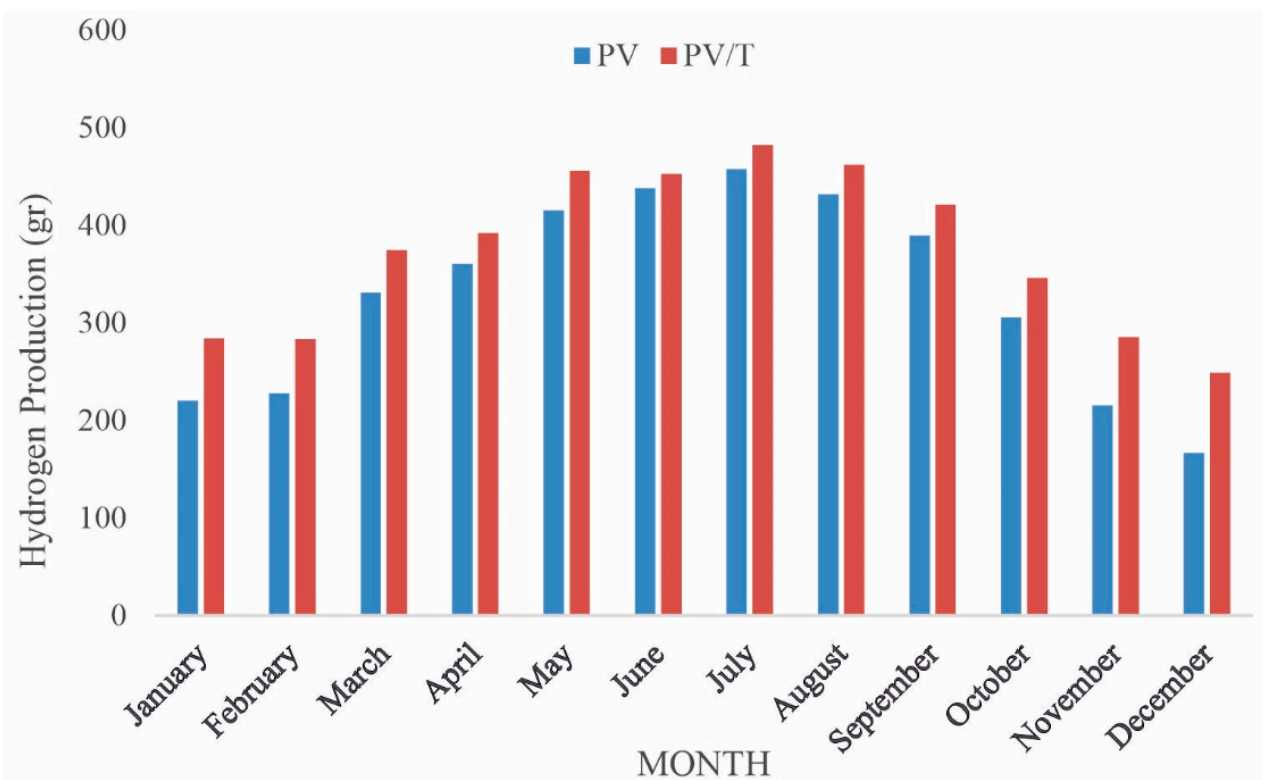

Figure 12. Comparison of monthly hydrogen production amounts for PV and PV/T.

The distribution of hydrogen generation based on the amount of solar radiation was calculated. Intervals of $100 \mathrm{~W} / \mathrm{m}^{2}$ of solar irradiation were used for the distribution of hydrogen production. The distribution of the annual hydrogen generation distribution with respect to the global solar radiation was studied and illustrated. It was calculated that the highest hydrogen production occurs 
in the range of $800-900 \mathrm{~W} / \mathrm{m}^{2}$, which accounts for $11.67 \%$ of the total amount of annual hydrogen generation (Figure 13).

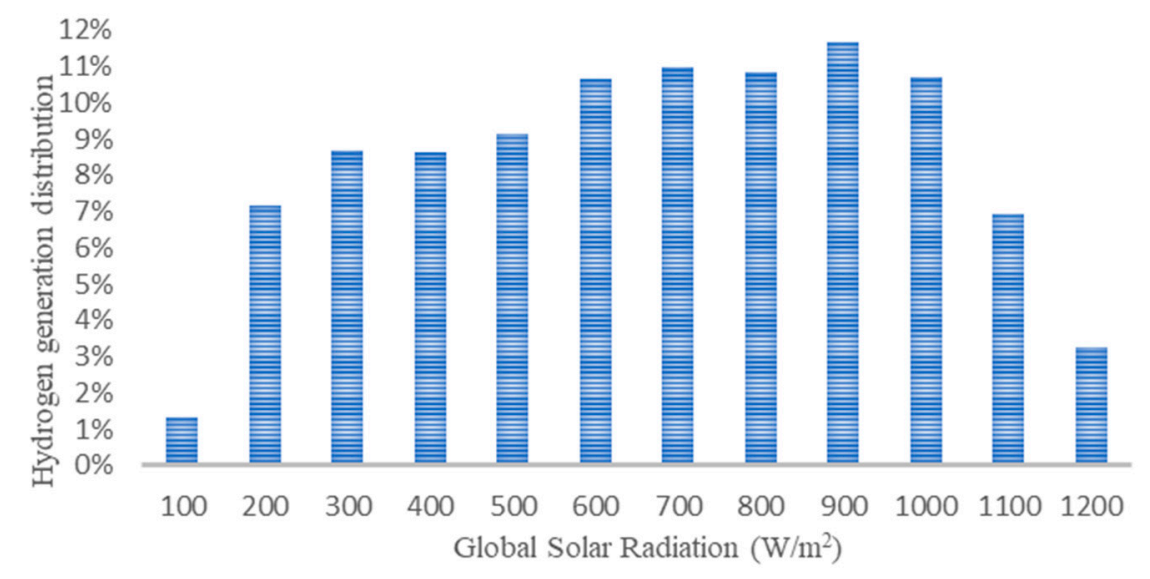

Figure 13. Variation of hydrogen generation distribution with respect to solar radiation.

Finally, in order to compare the cost of hydrogen production for both the PV and PV/T-E systems, economic analysis was carried out for each system. The total net present cost and hydrogen production costs were calculated as USD 638.62 and $4.87 \mathrm{USD} / \mathrm{kg}$ for the PV electrolyzer. These same values were calculated as $837.6 \$$ and $5.61 \mathrm{USD} / \mathrm{kg}$ for the PV/T E system implemented in Balikesir, Turkey.

The calculated cost values for hydrogen vary quite dynamically. On a yearly basis, the cost was affected by economic indicators such as inflation and discount rate, showing a decrease in PV capital. At this point, since the PV/T capital cost value of the PV/T system is high, the cost of hydrogen value was calculated as higher than the PV capital cost.

\section{Conclusions}

In this study, thermodynamic and economic analysis of a small-scale PV/T E system were carried out, and the numerical model of the system was validated with the experimental results. The annual amounts of electrical-thermal energy and production of hydrogen were calculated.

Comprehensive energy and exergy analyses were carried out for both the PV/T and PEM electrolyzer. The total PV/T energy and exergy efficiencies were calculated in the ranges of $35-60 \%$ and $13.7-15.8 \%$, respectively. When the current and operating temperature were in the respective ranges of $400-2350 \mathrm{~mA} / \mathrm{cm}^{2}$ and $28.1-45.8^{\circ} \mathrm{C}$, the PEM electrolyzer energy and the exergy efficiency were calculated in the ranges of $57.7-69.59 \%$ and $54.3-60.7 \%$, respectively.

The annual amounts of electrical, thermal, and hydrogen production by the PV/T E hybrid system were calculated with the numeric model as $556.8 \mathrm{kWh}, 1912 \mathrm{kWh}$, and $4.491 \mathrm{~kg} / \mathrm{year}$, respectively. It was observed that the highest hydrogen production occurs in the range of $800-900 \mathrm{~W} / \mathrm{m}^{2}$, which accounts for $11.67 \%$ of the total amount of annual hydrogen generation.

Furthermore, a comparison of the hydrogen production performance of the system with a PV-electrolyzer was conducted, and an annual amount of $3.96 \mathrm{~kg}$ of hydrogen production was calculated for the PV system, while it was $4.49 \mathrm{~kg}$ for the PV/T system. Due to its higher efficiency, the PV/T system produced $13 \%$ more hydrogen than the PV system.

The effect of a higher operation temperature on hydrogen production was also studied. The amount of hydrogen production using a $65^{\circ} \mathrm{C}$ operation temperature was compared to that produced in the actual operation temperature under the same conditions. The annual hydrogen production amounts were $4.593 \mathrm{~kg}$ and $4.491 \mathrm{~kg}$, respectively.

The levelized cost of hydrogen production for both the PV/E and PV/T E systems were calculated as $4.87 \mathrm{USD} / \mathrm{kg}$ and $5.61 \mathrm{USD} / \mathrm{kg}$, respectively, for systems utilized in Balikesir, Turkey. The values of the calculated hydrogen $\mathrm{kg}$ cost values varied quite dynamically. 
Author Contributions: All authors conducted this study. Conceptualization, E.A., M.G.; methodology, E.A.; software, E.A. and M.G.; validation, E.A. and M.G.; formal analysis, E.A. and M.G.; investigation, E.A. and M.G.; resources, E.A. and M.G.; data curation, E.A. and M.G.; writing—original draft preparation, E.A. and M.G.; writing-review and editing, E.A. and M.G.; visualization, E.A. and M.G.; supervision, E.A.; project administration, E.A. All authors have read and agreed to the published version of the manuscript.

Funding: This research was funded by [Balıkesir University Research Project (BAP)] grant number (2017-163).

Conflicts of Interest: The authors declare no conflict of interest.

\section{Nomenclature and Subscripts}

Nomenclature

$\mathrm{I}_{\mathrm{T}} \quad$ Inclined solar radiation $\left(\mathrm{W} / \mathrm{m}^{2}\right)$

$\mathrm{Q}_{\mathrm{u}} \quad$ Useful energy (w)

$\mathrm{U}_{\mathrm{L}} \quad$ Overall heat loss coefficient $\left(\mathrm{w} / \mathrm{m}^{2}{ }^{\circ} \mathrm{C}\right)$

W Width of the tube spacing (m)

D Diameter of copper tube (m)

$\tau \quad$ Transmissivity of glass

$\alpha_{\mathrm{g}} \quad$ Absorptivity of glass

$\mathrm{C}_{\mathrm{p}} \quad$ Water specific heat, $\mathrm{j} \mathrm{kg}^{-1} \mathrm{k}^{-1}$

$\mathrm{k} \quad$ Specific heat rate

$\mathrm{F}^{\prime} \quad$ Collector efficiency factor

$\mathrm{F}_{\mathrm{R}} \quad$ Collector flow rate factor

$\mathrm{n} \quad$ Number of electron

p Partial pressure

z Stoichiometric coefficient of electron

$\alpha \quad$ Transfer coefficient

h Overpotential

$\delta \quad$ Membrane thickness

s Membrane conductivity

r Material resistivity

i Current density

$i_{o} \quad$ Exchange current density

$\mathrm{P} \quad$ Operating pressure

$\Delta \mathrm{H} \quad$ Enthalpy change

$\Delta S \quad$ Entropy change

$\mathrm{R} \quad$ Universal gas constant

F Faraday's constant

z Stoichiometric coefficient

T Temperature

$\lambda$ Degree of humidification

m Mass flow rate $(\mathrm{kg} / \mathrm{s})$

Er Reversible voltage

Ex Exergy

$\Delta \mathrm{G} \quad$ Gibbs free energy

$\mathrm{E}_{0} \quad$ Reversible potential of water splitting

$\delta \quad$ Thickness

$\dot{\mathrm{E}} \quad$ Corresponding rate of exergy input

\section{Subscripts}

A Ambient

in Inlet

o Outlet

a Anode

c Cathode

rev Reversible voltage

th Thermal

e Electrical

t Total

m Membrane

$\mathrm{H}_{2} \mathrm{O}$ Water

$\mathrm{O}_{2} \quad$ Oxygen

$\mathrm{H}_{2} \quad$ Hydrogen

ph Physical

ch Chemical

elc Electrolyzer

ohm Ohmic

act Activation

LHV Lower heat value

$\eta \quad$ Efficiency

A Surface area $\left(\mathrm{m}^{2}\right)$

PEM Polymer electrolyte membrane

PV Photovoltaic

PV/T Photovoltaic/Thermal

sim Simulation

Exp Experimental

TLCC Total life-cycle cost

$\mathrm{f}^{\prime} \quad$ Inflation

CoE Cost of energy

$\mathrm{N} \quad$ Lifetime (year)

$\mathrm{R}^{\prime} \quad$ Real discount rate

$i^{\prime} \quad$ Nominal discount rate

CRF Capital recovery factor

TPV Total present value

r Reactant

p Product

HOMER Hybrid optimization model for

\section{References}

1. Li, W.; Liu, T.; Liu, X.; Hu, X. Thermodynamic analysis and optimization of photovoltaic/thermal hybrid hydrogen generation system based on complementary combination of photovoltaic cells and proton exchange membrane electrolyzer. Energy Convers. Manag. 2019, 183, 97-108. 
2. Ramzy, K.; El Elnaghi, B.; Ismail, T.; Abd El-Salam, M.; Abewahab, M.N. Using MATLAB to model and simulate a photovoltaic system to produce hydrogen. Energy Convers. Manag. 2019, 185, 101-129.

3. International Energy Agency, IEA. Energy Climateand Change-World Energy Outlook Special Report, Special Report on Energy and Climate Change; IEA: Paris, France, 2015.

4. Nazri, N.S.; Fudholi, A.; Bakhtyar, B.; Yen, C.H.; Ibrahim, A.; Ruslan, M.H.; Mat, S. Energy economic analysis of photovoltaicethermal-thermoelectric (PVT-TE) air collectors. Renew. Sustain. Energy Rev. 2018, 92, 187-197. [CrossRef]

5. Tripanagnostopoulos, Y. Aspects and improvements of hybrid photovoltaic/thermal solar energy systems. Sol. Energy 2007, 81, 1117-1131. [CrossRef]

6. Tripanagnostopoulos, Y.; Nousia, T.; Souliotis, M.; Yianoulis, P. Hybrid photovoltaic/thermal solar system. Sol. Energy 2002, 72, 217-234. [CrossRef]

7. Huang, B.J.; Lin, T.H.; Hung, W.C.; Sun, F.S. Performance evaluation of solar photovoltaic/thermal systems. Sol. Energy 2001, 70, 443-448. [CrossRef]

8. Tiwari, A.; Sodha, M.S. Performance evaluation of solar PV/T system: An experimental validation. Sol. Energy 2006, 80, 751-759. [CrossRef]

9. Chow, T.T. A review on photovoltaic/thermal hybrid solar technology. Appl. Energy 2010, 87, 365-379. [CrossRef]

10. Arif, H.M.; Sumathy, K. Photovoltaic thermal module concepts and their performance analysis: A review. Renew. Sustain. Energy 2010, 14, 1845-1859.

11. Tiwari, G.N.; Mishra, R.K.; Solanki, S.C. Photovoltaic modules and their applications: A review on thermal modelling. Appl. Energy 2011, 88, 2287-2304. [CrossRef]

12. Tyagi, V.V.; Kaushik, S.C.; Tyagi, S.K. Avancement in solar photovoltaic/thermal (PV/T) hybrid collector technology. Renew Sustain. Energy 2012, 16, 1383-1398. [CrossRef]

13. Wolf, M. Performance analysis of combined heating and photovoltaic power systems for residences. Energy Convers. Manag. 1976, 16, 79-90. [CrossRef]

14. Khelifa, A.; Touafek, K.; Ben Moussa, H. Approach for the modelling of hybrid photovoltaic-thermal solar collector. IET Renew. Power Gener. 2015, 9, 207-217. [CrossRef]

15. Bergene, T.; Løvvik, O.M. Model calculations on a flat-plate solar heat collector with integrated solar cells. Sol. Energy 1995, 55, 453-462. [CrossRef]

16. Matuska, T. Performance and economic analysis of hybrid PVT collectors in solar DHW system. Energy Proc. 2014, 48, 150-156. [CrossRef]

17. Singh, H.; Jain, A.; Singh, A.; Arora, S. Influence of absorber plate shape factor and mass flow rate on the performance of the PVT system. Appl. Therm. Eng. 2019, 156, 1016.

18. Touafek, K.; Khelifa, A.; Adouane, M. Theoretical and experimental study of sheet and tubes hybrid PVT collector. Energy Convers. Manag. 2014, 80, 71-77. [CrossRef]

19. Ibrahim, A.; Othman, M.Y.; Ruslan, M.H.; Mat, S.; Sopian, K. Recent advances in flat plate photovoltaic/thermal (PV/T) solar collectors. Renew. Sustain. Energy 2011, 15, 352-365. [CrossRef]

20. Choi, H.; Choi, K.H. Performance Evaluation of PV/T Air Collector Having a Single-Pass Double-Flow Air Channel and Non-Uniform Cross-Section Transverse Rib. Energies 2020, 13, 2203. [CrossRef]

21. Kim, J.; Ahn, J.G.; Kim, J.T. Demonstration of the Performance of an Air-Type Photovoltaic Thermal (PVT) System Coupled with a Heat-Recovery Ventilator. Energies 2016, 9, 728. [CrossRef]

22. Calise, F.; Figaj, R.; Vanoli, L. Experimental and Numerical Analyses of a Flat Plate Photovoltaic/Thermal Solar Collector. Energies 2017, 10, 491. [CrossRef]

23. Sakhr, M.; Ervina, E.; Saqaff, A. Theoretical study of new configuration of PVT system design. J. Adv. Mater. Res. 2013, 681-687.

24. Fudholi, A.; Sopian, K.; Yazd1, M.; Ruslan, I.; Kazem, H. Performance Analysis of Photovoltaic Thermal (PVT) Water Collectors. Energy Convers. Manag. 2014, 78, 641-651. [CrossRef]

25. Ibrahim, A.; Fudholi, A.; Sopian, K.; Othman, M.; Ruslan, M.H. Efficiencies and improvement potential of building integrated photovoltaic thermal (BIPVT) system. Energy Convers. Manag. 2014, 77, 527-534. [CrossRef]

26. Nualboonrueng, T.; Tuenpusa, P.; Ueda, Y.; Akisawa, A. Field Experiments of PV-Thermal Collectors for Residential Application in Bangkok. Energies 2012, 5, 12-29. [CrossRef] 
27. Guarracino, I.; Freeman, J.; Ekins-Daukes, N.; Markides, C.N. Performance assessment and comparison of solar orc and hybrid pvt systems for the combined distributed generation of domestic heat and power. In Proceedings of the 12th International Conference on Heat Transfer, Fluid Mechanics and Thermodynamics 2016, Costa del Sol, Spain, 11-13 July 2016.

28. Shekardasht, S.; Canli, E.; Ateş, A. Solar energy supported hydrogen production: A theoretical case study. Selcuk Univ. J. Eng. Sci. Technol. 2017, 5, 536-554.

29. Chong, L. Intelligent Renewable Energy Storage and Management System for Rural Household. Ph.D. Thesis, University of Nottingham, Nottingham, UK, 2020.

30. Yan, T.; Li, T.X.; Wang, R.Z. Thermochemical heat storage for solar heating and cooling systems. Adv. Sol. Heat. Cool. 2016, 10, 1016.

31. Jain, S.; Agrawal, N. Storage of Renewable Energy Using Phase Change Materials (PCMs); WAITRO: New Delhi, India, 2012.

32. Ineneji, C.; Bamisile, O.; Kuşaf, M. Super-Capacitors as an Alternative for Renewable Energy Unstable Supply. Acad. Perspect. Procedia 2018, 1, 11-20. [CrossRef]

33. Arias, P.L.; Cambra, J.; Bilbao, M.; Barrio, V.L.; Requies, J. Hydrogen as a new energy vector. Dyna Bilbao 2008, 83, 291-295.

34. Bozoglan, E.; Midilli, A.; Hepbasli, A. Sustainable assessment of solar hydrogen production techniques. Energy 2012, 46, 85-93. [CrossRef]

35. Midilli, A.; Dincer, I. Hydrogen as a renewable and sustainable solution in reducing global fossil fuel consumption. Int. J. Hydrogen Energy 2008, 33, 4209-4222. [CrossRef]

36. Ni, M.; Leung, M.K.H.; Leung, D.Y.C. A review and recent developments in photo catalytic water splitting using TiO2 for hydrogen production. Renew. Sustain. Energy Rev. 2007, 11, 401-425. [CrossRef]

37. Barone, G.; Buonomano, A.; Forzano, C.; Palombo, A.; Panagopoulos, O. Photovoltaic thermal collectors: Experimental analysis and simulation model of an innovative low-cost water-based prototype. Energy 2019, 179, 502-516. [CrossRef]

38. Di Blasi, A.; Durso, C.; Baglio, V.; Antonucci, V.; Aricò, A.; Ornelas, R.; Matteucci, F.; Orozco, G.; Beltran, D.; Meas, Y.; et al. Preparation and evaluation of RuO2-IrO2, $\mathrm{IrO} 2-\mathrm{Pt}$ and $\mathrm{IrO} 2-\mathrm{Ta} 2 \mathrm{O} 5$ catalysts for the oxygen evolution reaction in an SPE electrolyzer. J. Appl. Electrochem. 2009, 39, 191-196. [CrossRef]

39. Siracusano, S.; Baglio, V.; Di Blasi, A.; Briguglio, N.; Stassi, A.; Ornelas, R. Electrochemical characterization of single cell and short stack PEM electrolyzers based on a nanosized $\mathrm{IrO} 2$ anode electrocatalyst. Int. J. Hydrogen Energy 2010, 35, 5558-5568. [CrossRef]

40. Millet, P.; Ngameni, R.; Grigoriev, S.A.; Mbemba, N.; Brisset, F.; Ranjbari, A. PEM water electrolyzers: From electrocatalysis to stack development. Int. J. Hydrogen Energy 2010, 35, 5043-5052. [CrossRef]

41. Millet, P.; Mbemba, N.; Grigoriev, S.A.; Fateev, V.N.; Aukauloo, A.; Etie'vant, C. Electrochemical performances of PEM water electrolysis cells and perspectives. Int. J. Hydrogen Energy 2011, 36, 4134-4142. [CrossRef]

42. Decourt, B.; Lajoie, B.; Debarre, R.; Soupa, O. The Hydrogen-Based Energy Conversion Fact Book; The SBC Energy Institute: Gravenhage, The Netherlands, 2014.

43. Carmo, M.; Fritz, D.; Mergel, J.; Stolten, D. A Comprehensive review on PEM water electrolysis. Int. J. Hydrogen Energy 2013, 38, 4901-4934. [CrossRef]

44. Bertuccioli, L.; Chan, A.; Hart, D.; Lehner, F.; Madden, B.; Standen, E. Study on Development of Water Electrolysis in the EU; Final Report in Fuel Cells and Hydrogen Joint Undertaking; FCH JU: Saint-Gilles, Belgium, 2014.

45. Demir, M.; Dincer, I. Development of a hybrid solar thermal system with TEG and PEM electrolyzer for hydrogen and power production. Int. J. Hydrogen Energy 2017, 42, 30044-30056. [CrossRef]

46. Barbir, F. PEM electrolysis for production of hydrogen from renewable energy sources. Sol. Energy 2005, 78, 661. [CrossRef]

47. Lodhi, M.A. Photovoltaics and hydrogen: Future energy options. Energy Convers. Manag. 1997, 38, $1881-1893$. [CrossRef]

48. Yunez-Cano, A.; González-Huerta, R.D.; Tufino-Velazquez, M.; Barbosa, R.; Escobar, B. Solar-hydrogen hybrid system integrated to a sustainable house in Mexico. Int. J. Hydrogen Energy 2016, 41, 19539-19545. [CrossRef]

49. Corumlu, V.; Ozsoy, A.; Ozturk, M. Thermodynamic studies of a novel heat pipe evacuated tube solar collectors based integrated process for hydrogen production. Int. J. Hydrogen Energy 2017, 43, 1060-1070. [CrossRef] 
50. Omar, M.; Altinisik, K. Simulation of hydrogen production system with hybrid solar collector. Int. J. Hydrogen Energy 2016, 41, 12836-12841. [CrossRef]

51. Zafar, S.; Dincer, I. Thermodynamic analysis of a combined PV/T-fuel cell system for power, heat, fresh water and hydrogen production. Int. J. Hydrogen Energy 2014, 39, 9962-9972. [CrossRef]

52. Oruc, M.E.; Desai, A.V.; Kenis, P.J.A.; Nuzzo, R.G. Comprehensive energy analysis of a photovoltaic thermal water electrolyzer. Appl. Energy 2016, 164, 294-302. [CrossRef]

53. Ratlamwala, T.A.H.; Gadalla, M.A.; Dincer, I. Performance assessment of an integrated PV/T and triple effect cooling system for hydrogen and cooling production. Int. J. Hydrogen Energy 2011, 36, 11282-11291. [CrossRef]

54. Çiloğullari, M.; Erden, M.; Karakilcik, M.; Dincer, I. Investigation of hydrogen production performance of a Photovoltaic and Thermal System. Int. J. Hydrogen Energy 2016, 42, 25447-25452.

55. Hosseini, S.E.; Butler, B. Design and Analysis of a Hybrid Concentrated Photovoltaic Thermal System Integrated with an Organic Rankine Cycle for Hydrogen Production. J. Therm. Anal. Calorim. 2020, 20. [CrossRef]

56. Simulink Index. Available online: https://www.mathworks.com/help/simulink/index.html (accessed on 5 April 2020).

57. Duffie, J.A.; Beckman, W.A. Solar Engineering of Thermal Processes; Wiley: Hoboken, NJ, USA, 2013.

58. Radziemska, E. Thermal performance of Si and GaAs based solar cells and modules: A review. Prog. Energy Combust. Sci. 2003, 29, 407-424. [CrossRef]

59. Zhang, H.; Lin, G.; Chen, J. Evaluation and calculation on the efficiency of a water electrolysis system for hydrogen production. Int. J. Hydrogen Energy 2010, 35, 10851-10858. [CrossRef]

60. Siracusano, S.; Baglio, V.; Briguglio, N. An electrochemical study of a PEM stack for water electrolysis. Int. J. Hydrogen Energy 2012, 37, 1939-1946. [CrossRef]

61. Singh, P.; Ravindra, N. Temperature dependence of solar cell performance-An analysis. Sol. Energy Mater. Sol. Cells 2012, 101, 36-45. [CrossRef]

62. Spiegel, C. PEM Fuel Cell Modeling and Simulation Using MATLAB; Academic Press: Cambridge, MA, USA, 2008.

63. Kazim, A. Exergoeconomic analysis of a PEM electrolyser at various operating temperatures and pressures. Int. J. Energy Res. 2005, 29, 539-548. [CrossRef]

64. Çengel, Y.A.; Boles, M.A. Thermodynamics: An Engineering Approach, 5th ed.; McGraw-Hill: New York, NY, USA, 2008.

65. Akyuz, E.; Coskun, C.; Oktay, Z.; Dincer, I. Hydrogen production probability distributions for a PV-electrolyser system. Int. J. Hydrogen Energy 2011, 36, 292-299. [CrossRef]

66. Ceicdata. Available online: https://www.ceicdata.com/en/turkey/saving-discount-rate-and-interbank-rate/ central-bank-discount-rate (accessed on 21 April 2020). 